\title{
Implementasi Teknologi Geofencing Untuk Pengawasan terhadap Lansia Menggunakan Sarung Lengan Berbasis Mikrokontroler dan Android
}

\author{
Amadiea permana Sanusi ${ }^{1}$, Aad Hariyadi ${ }^{2}$, M. Nanak Zakaria ${ }^{3}$ \\ 1,3 Program Studi Jaringan Telekomunikasi Digital, \\ Jurusan Teknik Elektro, Politeknik Negeri Malang, Indonesia \\ ${ }^{2}$ Program Studi Teknik Telekomunikasi, \\ Jurusan Teknik Elektro, Politeknik Negeri Malang, Indonesia \\ 19amadeapermanas@gmail.com, ${ }^{2}$ aad.hariyadi@polinema.ac.id, ${ }^{3}$ nanak zach@polinema.ac.id
}

\begin{abstract}
According to the World Health Organization (WHO), an elderly person is someone who has entered the age of 60 years and over. Based on recorded data from Radio Suara Surabaya from January 2017 to July 2019, Radio Suara Surabaya has received 618 listener reports of missing people due to dementia or senility. This research aims to provide an alternative in order to keep an eye on the presence of the elderly by utilizing the U-Blox Neo 6m GPS module and the ESP8266 NodeMCU microcontroller. In addition, supervisors can use an android application to implement geofence technology. The results of the research conducted gave the results by testing the GPS U-Blox Neo $6 \mathrm{~m}$ module placed in different locations and conditions resulting in receiving information signals obtained from 3-9 information satellites that send signals. The distance difference test was carried out at 10 different location points resulting in a difference in the distance from $1 \mathrm{~m}$ to $8 \mathrm{~m}$. In addition, there is data transmission delay testing carried out at different times of the morning, afternoon, and night which results in delays ranging from 0.2 seconds to 1 second. Based on the research conducted, it can be concluded that the implementation of geofence results in a geofence application that can apply geofence to the elderly by depicting a circle radius of $100 \mathrm{~m}$ based on the center point of a specified location. The use of GPS U-Blox Neo $6 \mathrm{~m}$ gives results by calculating the average distance difference of $3.7 \mathrm{~m}$.
\end{abstract}

Keywords— Geofence, Android, NodeMCU ESP8266, GPS U-Blox Neo 6m, Firebase

Abstrak-Menurut World Health Organisation (WHO), lansia adalah seseorang yang telah memasuki usia 60 tahun keatas. Berdasarkan data tercatat dari Radio Suara Surabaya mulai Januari 2017 sampai dengan Juli 2019, Radio Suara Surabaya telah menerima 618 laporan pendengar tentang orang hilang karena demensia atau pikun. Penelitian yang dilakukan bertujuan untuk memberikan alternatif agar tetap dapat mengawasi keberadaan lansia dengan memanfaatkan modul GPS U-Blox Neo 6m dan mikrokontroler NodeMCU ESP8266. Selain itu pengawas dapat menggunakan aplikasi android untuk mengimplementasikan teknologi geofence. Hasil dari penelitian yang dilakukan memberikan hasil dengan pengujian modul GPS U-Blox Neo 6m diletakkan pada lokasi dan kondisi yang berbeda menghasilkan penerimaan sinyal informasi didapat dari 3-9 satelit informasi yang mengirimkan sinyal. Pengujian selisih jarak dilakukan pada 10 titik lokasi yang berbeda menghasilkan selisih jarak dari $1 \mathrm{~m}$ hingga $8 \mathrm{~m}$. selain itu, terdapat pengujian delay pengiriman data yang dilakukan pada waktu yang berbeda dari pagi, siang, dan malam hari yang menghasilkan delay mulai dari 0.2 detik hingga 1 detik. Berdasarkan penelitian yang dilakukan dapat ditarik kesimpulan bahwa implementasi geofence menghasilkan aplikasi geofence dapat menerapkan geofence bagi lansia dengan penggambaran radius lingkaran sebesar $100 \mathrm{~m}$ berdasarkan titik pusat dari sebuah lokasi yang ditentukan. Penggunaan GPS U-Blox Neo 6m memberikan hasil dengan perhitungan rata-rata selisih jarak sebesar $3.7 \mathrm{~m}$

Kata kunci- Geofence, Android, NodeMCU ESP8266, GPS U-Blox Neo 6m, Firebase

\section{PENDAHULUAN}

Sebagian besar orang ingin berumur panjang dan dapat hidup sejahtera pada masa tuanya. Menurut World Health Organisation (WHO), lansia adalah seseorang yang telah memasuki usia 60 tahun keatas [1]. Berdasarkan data tercatat dari Radio Suara Surabaya mulai Januari 2017 sampai dengan Juli 2019, Radio Suara Surabaya telah menerima 618 laporan pendengar tentang orang hilang karena demensia atau pikun. Semua penderita demensia yang telah berusia 60 tahun ke atas tersebut dilaporkan hilang atau tersesat saat mereka sedang keluar rumah [2].

Permasalahan yang sering dialami adalah adanya tingkat kesulitan yang cukup tinggi bagi anggota keluarga untuk mengawasi lansia secara efektif mengingat kebanyakan anggota keluarga memiliki kesibukan tersendiri yang menyebabkan pengawasan terhadap lansia menjadi kurang intensif[3]. Seluruh anggota keluarga pasti akan merasa lebih tenang apabila mengetahui lokasi keberadaan dari lansia yang perlu diawasi ketika mereka masih dalam kesibukan tersendiri[4][5].

Pengawasan terhadap lansia akan menjadi lebih efektif apabila keluarga dapat mengetahui lokasi dan dapat menentukan sendiri dimana saja tempat-tempat aman yang dapat dikunjungi oleh lansia tersebut. Oleh karena itu, dalam penelitian ini diusulkan judul "Implementasi Geofencing Untuk Pengawasan Terhadap Lansia Menggunakan Sarung 
Lengan Berbasis Mikrokontroler dan Android". Pada penelitian ini menggunakan nodemcu esp8266 sebagai mikrokontrolernya[6]. Nodemcu esp8266 nantinya akan dirangkai bersama dengan modem sebagai penyedia koneksi internet dan modul GPS NEO 6M. Modul GPS ini berfugsi untuk mendapatkan titik koordinat lokasi objek yang berupa latitude dan longitude. Dalam penelitian ini modul GPS NEO $6 \mathrm{M}$ akan bekerja dengan efektif ketika berada di luar ruangan mengingat tingkat akurasi titik koordinat yang terdeteksi didapatkan banyaknya sinyal satelit yang diterima. Data ini akan dikirimkan dan disimpan pada database yang digunakan, yaitu Firebase Database. Penelitian ini menggunakan aplikasi android guna menerapkan geofencing.

\section{A. Rancangan Penelitian}

\section{METODE}

Rancangan yang akan digunakan dalam penelitian penelitian adalah pembuatan tahap-tahap pencarian informasi, pembuatan alat hingga pengujian, dalam skripsi yang disusun dengan maksud agar penelitian dilakukan secara terperinci dan terencana melalui tahap-tahap yang telah disusun sebelumnya.

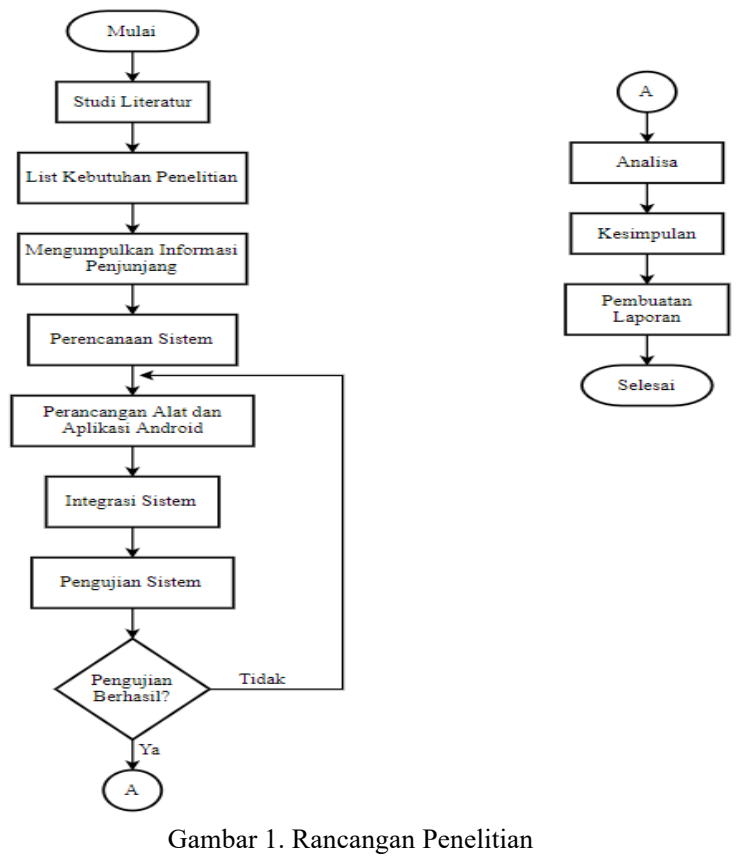

Langkah pertama studi literatur mengenai Geofence, NodeMCU ESP8266, Firebase, Aplikasi Android, komunikasi data pada sistem, dan lainnya. Pada tahap ini, ditentukan spesifikasi alat dan bahan, pemrograman yang digunakan, dan sistem komunikasi yang digunakan.

Langkah kedua melakukan list kebutuhan penelitian merupakan tahapan untuk menentukan kebutuhan perangkat seperti komponen, hardware, dan software pada penelitian yang akan dilakukan.

Langkah ketiga tahapan mengumpulkan informasi penunjang merupakan kegiatan untuk memperkuat pengetahuan sebagai landasan dalam melakukan penelitian yang akan dilakukan.
Langkah keempat perencanaan sistem membahas tentang perencanaan dan pembuatan desain perangkat dari sistem. Diantaranya, desain alat, pemrograman android, serta perkiraan letak perangkat yang digunakan.

Langkah kelima dalam penelitian ini akan dibuat alat untuk mendeteksi lokasi keberadaan lansia menggunakan microcontroller, serta pemanfaatan Geofence yang akan diterapkan teknologinya di aplikasi android.

Langkah keenam pada tahap ini alat yang dibuat akan diintegrasikan atau dihubungkan dengan aplikasi android sesuai dengan perencanaan sistem yang sudah dibuat.

Langkah ketujuh sistem yang telah dibuat sebelumnya, akan dilakukan uji coba apakah sistem yang telah dibuat memiliki hasil yang sesuai dengan harapan atau tidak. Jika tidak, akan dilakukan perencanaan sistem kembali.

Langkah kedelapan analisa sistem yang telah diuji diantaranya alat dan program dapat berjalan dengan sesuai, antara alat dan aplikasi dapat menerapkan geofencing, keakuratan lokasi yang dihasilkan dari alat yang dibuat.

Langkah kesembilan pada tahap ini merupakan pembuatan kesimpulan yang diambil berdasarkan rumusan masalah, pembutanan sistem serta hasil pengujian dan analisa yang dilakukan.

Langkah kesepuluh setelah analisa sistem dan kesimpulan selesai, maka dibuatkan laporan penelitian.

\section{B. Perencanaan Sistem}

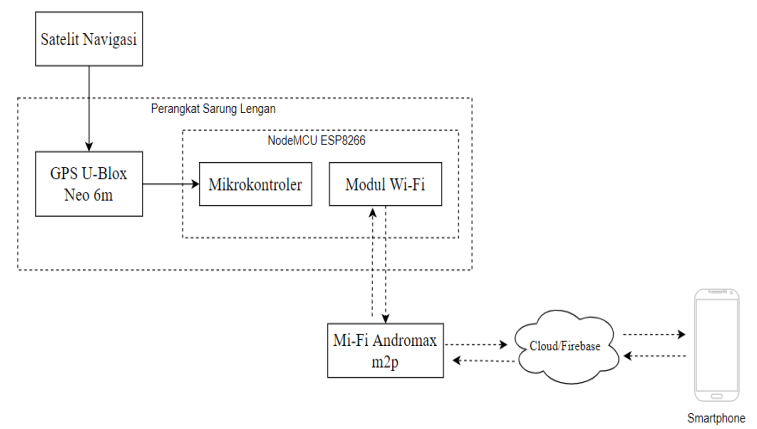

Gambar 2. Block Diagram Sistem

GPS U-Blox Neo 6m berfungsi untuk menerima sinyal informasi yang dikirimkan oleh satelit. Sinyal informasi tersebut berupa data-data yang berisi titik koordinat sebuah lokasi. Selanjutnya terdapat NodeMCU ESP8266 yang berfungsi sebagai microcontroller dalam system ini. NodeMCU terhubung dengan baterai sebagai supply daya serta Mi-Fi sebagai penyedia koneksi internet. Data berupa titik koordinat yang dimiliki oleh GPS akan dikirimkan ke NodeMCU yang sudah memiliki koneksi internet. NodeMCU akan mengirimkan data yang dimiliki melalui koneksi internet ke Firebase Database. Dalam database data titik koordinat disimpan dalam kolom tersendiri, data dari database tersebut akan dikirimkan kembali ke aplikasi android yang terinstall dalam smartphone dan ditampilkan dalam bentuk map menggunakan Google Maps API. 


\section{HASIL DAN PEMBAHASAN}

A. Hasil Implementasi Alat

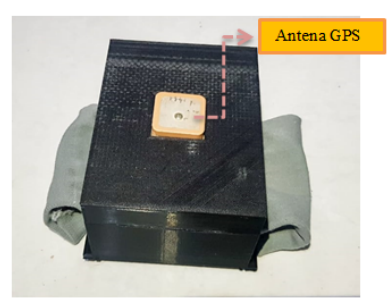

(a)

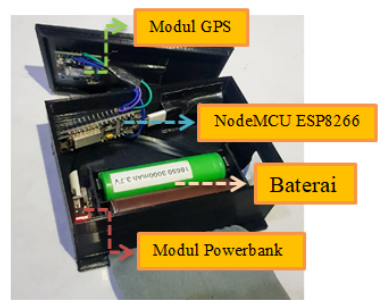

(b)
Gambar 3. (a)Tampak Luar, (b)Tampak Dalam Alat

Pada Gambar 3 menunjukkan pada sistem menggunakan dua baterai Li-Ion $3.7 \mathrm{~V}$ yang dirangkai secara pararel. Output dari baterai tersebut dirangkai dengan modul powerbank, sehingga keluaran dari modul powerbank yang digunakan sebagai supply pada sistem. Modul powerbank disambungkan dengan nodeMCU menggunakan kabel micro usb yang berfungsi sebagai supply untuk nodeMCU. Modul GPS diletakkan dibagian penutup dengan antena berada dibagian luar dari cover dengan tujuan untuk mempermudah modul GPS dalam penerimaan sinyal informasi dari satelit navigasi.

\section{B. Hasil Implementasi Aplikasi Android}

TABEL I

HASIL IMPLEMENTASI DESAIN APLIKASI ANDROID

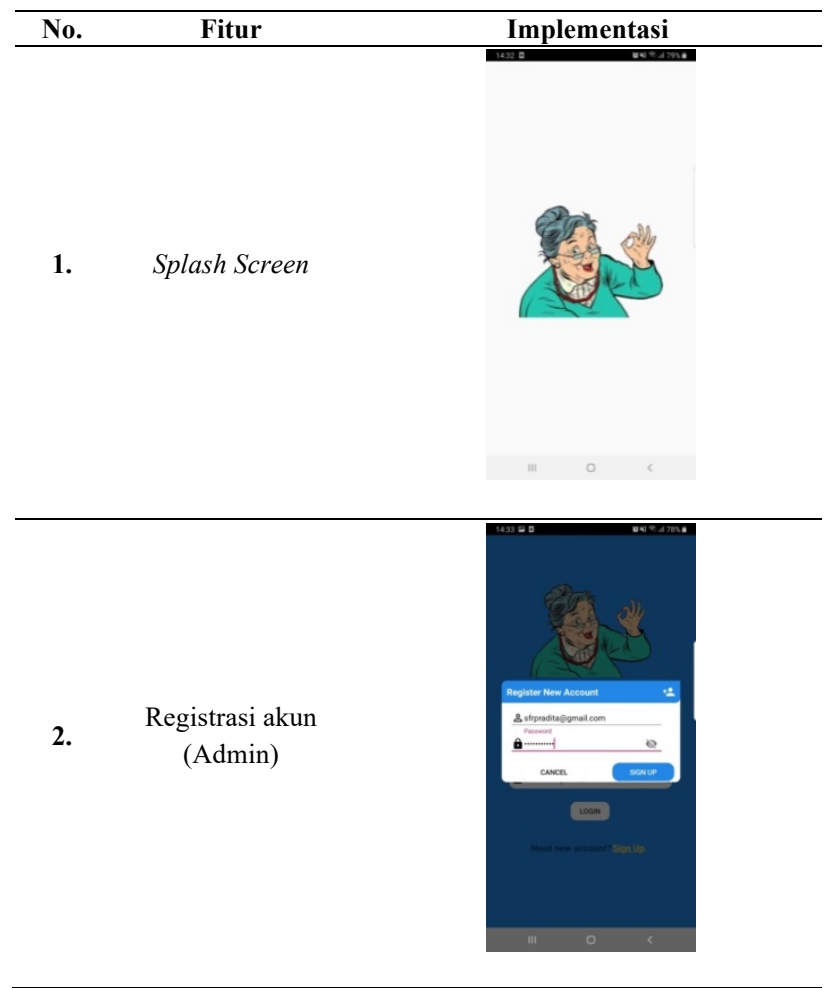

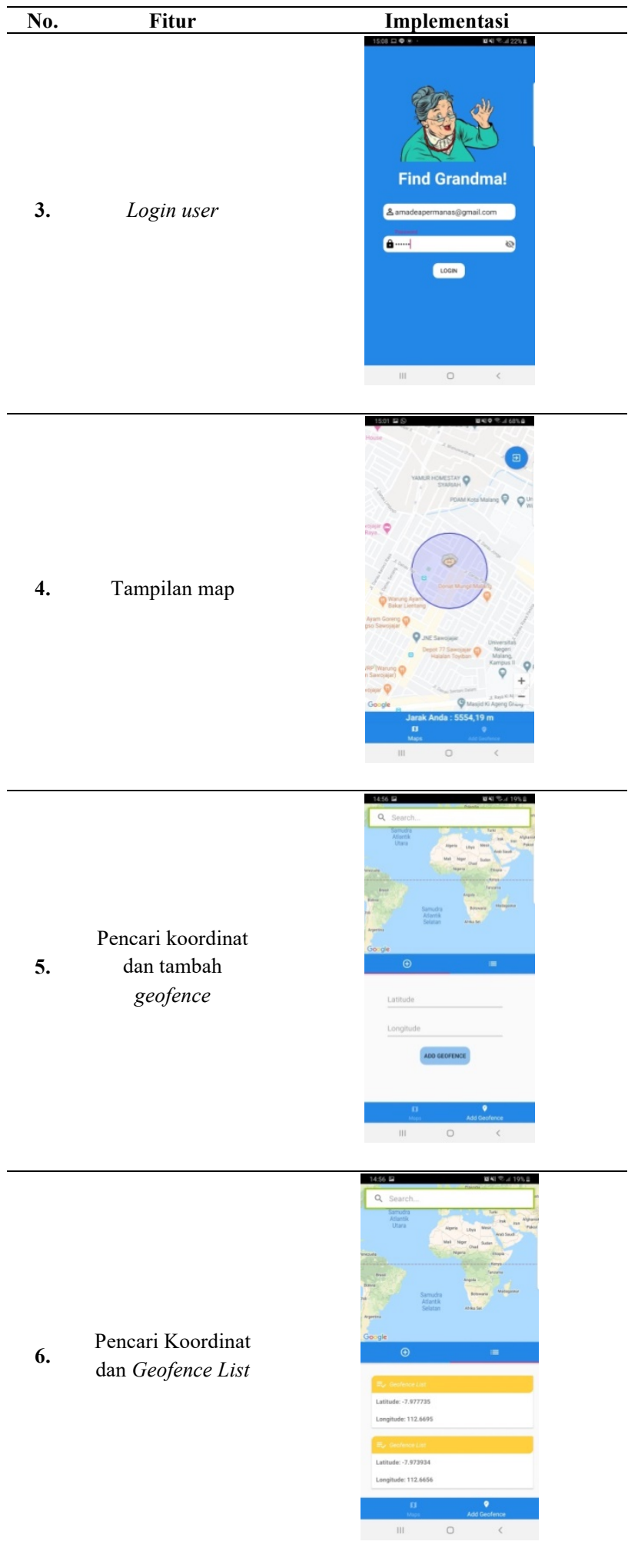

Tabel 1 menunjukkan hasil implementasi fitur pada aplikasi geofencing. Pada aplikasi terdapat beberapa fitur seperti registrasi akun (hanya dilakukan oleh admin), login user, tampilan map, pencarian koordinat, tambah geofence, dan geofence list. Dalam penggunaan geofence, pengguna harus 
menentukan titik pusat dari batas virtual yang akan digambarkan. Penentuan titik pusat dalam aplikasi geofencing dilakukan dengan memasukkan titik koordinat lokasi. Setelah pengguna berhasil menambahkan geofence yang diinginkan, pada tampilan map akan menampilkan gambaran geofence yang ditambahkan dengan radius lingkaran $200 \mathrm{~m}$. Aplikasi geofencing memanfaatkan library firebase geofire untuk menerapkan fungsi geofence sebagai batas wilayah virtual.

\section{Pengujian Alat}

TABEL II

PENGUJIAN MENGGUNAKAN SOFTWARE U-CENTER (DALAM GEDUNG)

Sinyal yang Diterima
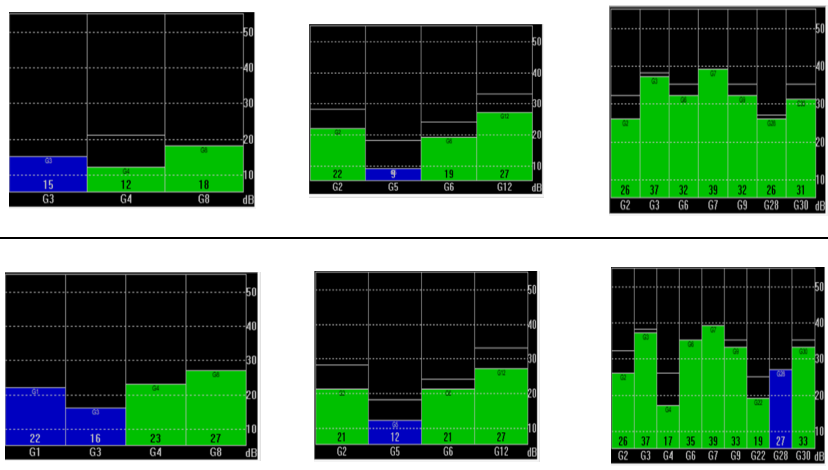

Kondisi pada saat modul GPS berada di dalam Gedung AH Polinema mempengaruhi sinyal yang diterima oleh modul GPS karena adanya bangunan dapat mempengaruhi sinyal yang dikirimkan oleh satelit navigasi. Hasil yang didapatkan yaitu pada saat berada di dalam gedung modul GPS menerima sinyal dari 3-4 satelit navigasi. Kondisi pada saat modul GPS berada di Hutan Kota Malabar mempengaruhi sinyal yang diterima oleh modul GPS karena adanya pepohonan tinggi dapat mempengaruhi sinyal yang dikirimkan oleh satelit navigasi. Hasil yang didapatkan yaitu pada saat berada di hutan malabar modul GPS menerima sinyal dari 4 satelit navigasi. Kondisi pada saat modul GPS berada di Lapangan Kendalsari mempengaruhi sinyal yang diterima oleh modul GPS karena banyaknya benda yang berada disekitar alat GPS dapat mempengaruhi sinyal yang dikirimkan oleh satelit navigasi. Hasil yang didapatkan yaitu pada saat berada di lapangan modul GPS menerima sinyal dari 6-9 satelit navigasi. Pada parameter tabel satelit navigasi, terdapat tiga buah warna yaitu satelit berwarna merah mendakan terdapat satelit yang tertangkap oleh modul GPS namun tidak mengirimkan sinyal sama sekali, satelit berwarna biru menandakan terdapat satelit yang mengirimkan sinyal namun sinyal tersebut tidak dapat digunakan untuk melakukan navigasi, dan satelit berwarna hijau menandakan satelit mengirimkan sinyal yang dapat digunakan untuk melakukan navigasi. Dalam pengujian yang dilakukan, modul GPS tidak dapat menerima sinyal dengan stabil karena pengaruh halangan yang terdapat pada lokasi pengujian.

TABEL III

PENGUJIAN PERBANDINGAN TITIK KOORDINAT

\begin{tabular}{|c|c|c|c|c|}
\hline \multicolumn{2}{|c|}{$\begin{array}{c}\text { Titik Koordinat U- } \\
\text { Center }\end{array}$} & \multicolumn{2}{c|}{$\begin{array}{c}\text { Titik Koordinat Firebase } \\
\text { Database }\end{array}$} & \multirow{2}{*}{$\begin{array}{c}\text { Selisih } \\
\text { Jarak }\end{array}$} \\
\hline Latitude & Longitude & Latitude & Longitude & \\
\hline-7.97280 & 112.66736 & -7.9727628 & 112.6673612 & $4.9 \mathrm{~m}$ \\
\hline-7.96746 & 112.66196 & -7.9674408 & 112.6619978 & $4.38 \mathrm{~m}$ \\
\hline-7.97333 & 112.66106 & -7.9733448 & 112.6610752 & $1.82 \mathrm{~m}$ \\
\hline-7.97549 & 112.66254 & -7.9755023 & 112.6625398 & $1.05 \mathrm{~m}$ \\
\hline-7.97522 & 112.66303 & -7.9752233 & 112.6630677 & $3.17 \mathrm{~m}$ \\
\hline-7.97397 & 112.66558 & -7.9739932 & 112.6655837 & $2.05 \mathrm{~m}$ \\
\hline-7.97542 & 112.66585 & -7.9754152 & 112.6658850 & $3.59 \mathrm{~m}$ \\
\hline-7.96770 & 112.66400 & -7.9676573 & 112.6640637 & $8.3 \mathrm{~m}$ \\
\hline-7.96821 & 112.66381 & -7.9682327 & 112.6637895 & $3.29 \mathrm{~m}$ \\
\hline-7.97772 & 112.66951 & -7.977720 & 112.6694772 & $4.43 \mathrm{~m}$ \\
\hline \multicolumn{5}{|c|}{ Rata-rata selisih jarak } \\
\hline
\end{tabular}

Tabel 3 menunjukkan hasil pengujian perbandingan titik koordinat untuk mengetahui selisih jarak dari titik koordinat yang dibandingkan. Salah satu titik lokasi yang digunakan pada pengujian ini pada Jl. Danau Bratan Timur IV dengan titik koordinat (longitude dan latitude) pada software u-center 7.97280767 dan 112.66736300, lalu titik koordinat (longitude dan latitude) pada firebase database yaitu -7.9727628 dan 112.6673612. Berdasarkan titik koordinat tersebut dapat dihitung selisih jarak antara kedua titik koordinat yang didapatkan dengan menggunakan rumus berikut dengan nilai $\mathrm{km}$ diambil dari perbandingan $1^{\circ}$ degree decimal sama dengan $111.32 \mathrm{~km}$.

$$
\begin{gathered}
S(\mathrm{~km})=\sqrt{(\text { Lat } x-\text { Lat } y)^{2}+(\text { Long } x-\text { Long } y)^{2}} \times 111.32 \mathrm{~km} \\
S(\mathrm{~km})=0.0000449 \mathrm{~km} \times 111.32 \mathrm{~km} \\
S(\mathrm{~km})=0.0049 \mathrm{~km} \\
S(\text { meter })=4.9 \mathrm{~m}
\end{gathered}
$$

Tabel 3 menunjukkan hasil selisih jarak dengan nilai ratarata selisih jarak sebesar $3.7 \mathrm{~m}$. Nilai selisih jarak terbesar yang didapatkan pada pengujian yaitu $8.3 \mathrm{~m}$, hal ini dapat disebabkan oleh kondisi lokasi pengambilan data titik koordinat memiliki banyak penghalan seperti pepohonan atau bangunan di sekitar modul GPS yang menyebabkan penerimaan sinyal informasi yang dikirimkan oleh satelit navigasi dapat terganggu. 


\section{Pengujian Aplikasi Android}

TABEL IV

PENGUJIAN GEOFANCING PADA APLIKASI ANDROID

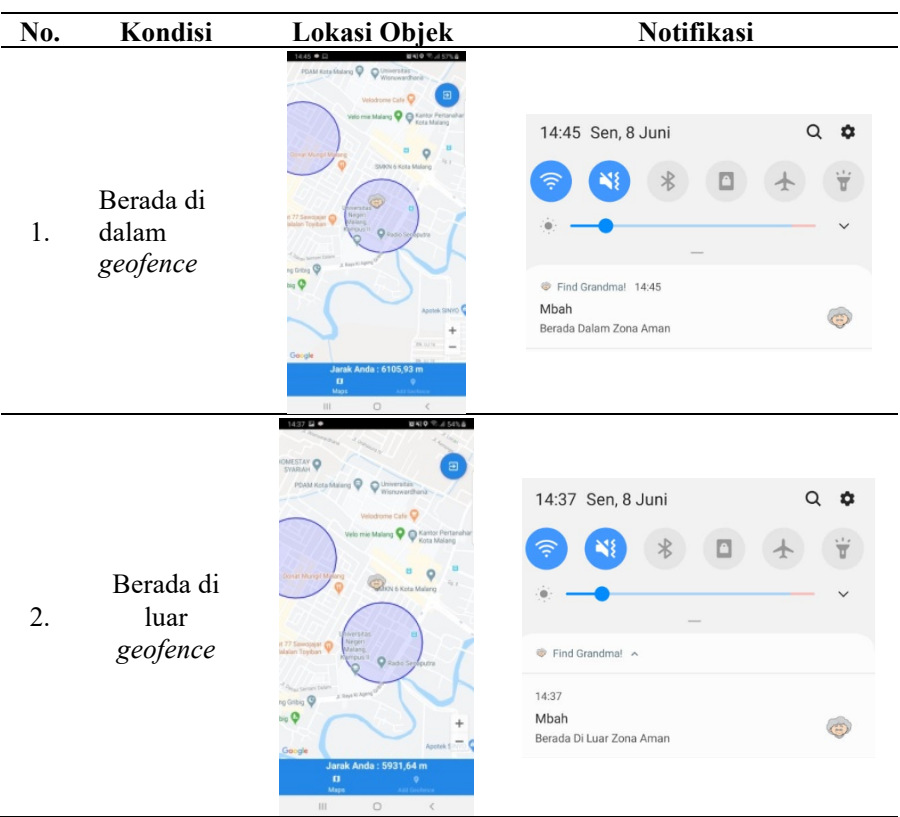

Berdasarkan hasil pengujian Tabel 4 ketika objek memasuki geofence, aplikasi akan memberikan notifikasi berupa pemberitahuan bahwa objek berada di dalam zona aman, sedangkan ketika lokasi objek keluar dari geofence maka aplikasi memberikan notifikasi berupa pemberitahuan bahwa objek berada di luar zona aman. Aplikasi geofencing secara langsung memberikan notifikasi kepada pengguna dengan pembuktian waktu yang didapatkan. Pada kondisi objek berada di luar geofence waktu menunjukkan pukul 14.37 WIB dan notifikasi muncul pada waktu yang sama yaitu 14.37 WIB. Hal serupa berlaku pada kondisi ketika objek berada di dalam zona aman dengan waktu yang ditunjukkan yaitu 14.45 WIB dan notifikasi muncul pada waktu yang sama yaitu 14.45 WIB.

\section{E. Pengujian Delay Pengiriman Data oleh NodeMCU ESP 8266}

TABEL V

TABEL PENGUJIAN DELAY DATA (PAGI)

\begin{tabular}{cccc}
\hline No. & Source & $\begin{array}{c}\text { Time delta from } \\
\text { previous displayed } \\
\text { frame (detik) }\end{array}$ & Delay (detik) \\
\hline $\mathbf{1 .}$ & 192.168 .8 .101 & 0 & 0.205095000 \\
\hline $\mathbf{2 .}$ & 192.168 .8 .101 & 4.711507000 & 0.201012000 \\
\hline $\mathbf{3 .}$ & 192.168 .8 .101 & 6.860239000 & 0.312247000 \\
\hline $\mathbf{4 .}$ & 192.168 .8 .101 & 8.699190000 & 0.409081000 \\
\hline $\mathbf{5 .}$ & 192.168 .8 .101 & 2.563914000 & 0.303032000 \\
\hline $\mathbf{6 .}$ & 192.168 .8 .101 & 4.608995000 & 0.606034000 \\
\hline $\mathbf{7 .}$ & 192.168 .8 .101 & 2.867858000 & 0.311512000 \\
\hline $\mathbf{8 .}$ & 192.168 .8 .101 & 2.560718000 & 1.334285000 \\
\hline $\mathbf{9 .}$ & 192.168 .8 .101 & 3.481753000 & 0.303191000 \\
\hline $\mathbf{1 0 .}$ & 192.168 .8 .101 & 5.938051000 & 0.309615000 \\
\hline \multicolumn{6}{r}{ Rata-rata } & & 0.429 \\
\hline
\end{tabular}

TABEL VI

TABEL PENGUJIAN DELAY PENGIRIMAN DATA (SIANG)

\begin{tabular}{cccc}
\hline No. & Source & $\begin{array}{c}\text { Time delta from } \\
\text { previous displayed } \\
\text { frame (detik) }\end{array}$ & Delay (detik) \\
\hline $\mathbf{1 .}$ & 192.168 .8 .101 & 0 & 0.310629000 \\
\hline $\mathbf{2 .}$ & 192.168 .8 .101 & 3.757085000 & 0.309547000 \\
\hline $\mathbf{3 .}$ & 192.168 .8 .101 & 9.523570000 & 0.409175000 \\
\hline $\mathbf{4 .}$ & 192.168 .8 .101 & 3.787026000 & 0.409511000 \\
\hline $\mathbf{5 .}$ & 192.168 .8 .101 & 2.662048000 & 0.307727000 \\
\hline $\mathbf{6 .}$ & 192.168 .8 .101 & 3.685083000 & 0.513254000 \\
\hline $\mathbf{7 .}$ & 192.168 .8 .101 & 1.537303000 & 0.408459000 \\
\hline $\mathbf{8 .}$ & 192.168 .8 .101 & 1.640359000 & 0.205046000 \\
\hline $\mathbf{9 .}$ & 192.168 .8 .101 & 3.792235000 & 0.205037000 \\
\hline $\mathbf{1 0 .}$ & 192.168 .8 .101 & 3.893033000 & 0.305419000 \\
\hline \multicolumn{5}{r}{ Rata-rata } \\
\hline
\end{tabular}

TABEL VII

TABEL PENGUJIAN DELAY PENGIRIMAN DATA (MALAM)

\begin{tabular}{cccc}
\hline No. & Source & $\begin{array}{c}\text { Time delta from } \\
\text { previous displayed } \\
\text { frame (detik) }\end{array}$ & Delay (detik) \\
\hline $\mathbf{1 .}$ & 192.168 .8 .101 & 0 & 0.422656000 \\
\hline $\mathbf{2 .}$ & 192.168 .8 .101 & 1.575931000 & 0.341465000 \\
\hline $\mathbf{3 .}$ & 192.168 .8 .101 & 7.617926000 & 0.283232000 \\
\hline $\mathbf{4 .}$ & 192.168 .8 .101 & 6.866205000 & 0.290818000 \\
\hline $\mathbf{5 .}$ & 192.168 .8 .101 & 4.625988000 & 0.289494000 \\
\hline $\mathbf{6 .}$ & 192.168 .8 .101 & 2.773653000 & 0.351789000 \\
\hline $\mathbf{7 .}$ & 192.168 .8 .101 & 4.594618000 & 0.291853000 \\
\hline $\mathbf{8 .}$ & 192.168 .8 .101 & 1.597914000 & 0.304642000 \\
\hline $\mathbf{9 .}$ & 192.168 .8 .101 & 3.689077000 & 0.290684000 \\
\hline $\mathbf{1 0 .}$ & 192.168 .8 .101 & 2.738793000 & 0.307854000 \\
\hline \multicolumn{5}{c}{ Rata-rata } & 0.317 \\
\hline
\end{tabular}

Tabel 5, Tabel 6, dan Tabel 7 menunjukkan data hasil pengujian delay pengiriman data oleh NodeMCU ESP8266 ke Firebase Database. Pengujian dilakukan pada pagi, siang, dan malam yang menunjukkan delay pengiriman data selalu berubah-ubah mulai dari 0.2 detik hingga 1 detik. Hal ini dapat disebabkan oleh sinyal pada MiFi Andromax m2p tidak terlalu bagus sehingga mempengaruhi proses pengiriman data.

\section{KESIMPULAN}

Pembuatan sistem dapat menampilkan lokasi keberadaan objek dengan menggunakan modul GPS U-Blox Neo $6 \mathrm{~m}$ sebagai penerima sinyal infromasi dari satelit navigasi dan penggunaan Google Map API untuk tampilan map. Berdasarkan pengujian GPS U-Blox Neo $6 \mathrm{~m}$ tidak selalu stabil dalam penerimaan sinyal informasi. Berdasarkan hasil pengujian selisih jarak menghasilkan rata-rata yaitu $3.7 \mathrm{~m}$ yang dapat dikatakan cukup baik dalam kualitas ketelitian.

Integrasi antar sistem yang dibuat pada penelitian yang dilakukan memanfaatkan koneksi internet menggunakan $\mathrm{MiFi}$ Andromax $\mathrm{m} 2 \mathrm{p}$ yang menggunakan provider Smartfren. Berdasarkan pengujian delay pengiriman data didapatkan ratarata sebesar 0.429 detik di pagi hari, 0.338 detik di siang hari, dan 0.317 detik di malam hari, sehingga dapat dikatakan kualitas pengiriman data cukup baik.

Hasil pengujian menunjukkan notifikasi dari aplikasi geofencing cukup akurat. Penggunaan geofencing pada aplikasi android dapat diterapkan menggunakan library geofire. 
Aplikasi android memberikan notifikasi pada smartphone berupa tampilan notifikasi pada tab notification dan smartphone akan bergetar selama dua detik dengan pengulangan getaran dua kali. Respon aplikasi android berupa notifikasi muncul ketika objek masuk maupun keluar dari batas virtual/geofence.

\section{REFERENSI}

[1] Pemerintah Indonesia, 2005, Peraturan Pemerintah Indonesia Nomor 43 Tahun 2004 tentang Pelaksanaan Upaya Peningkatan Kesejahteraan Sosial Lanjut Usia, Lembaran Negara RI Tahun 2004, No. 4451, Sekretariat Negara, Jakarta.

[2] Syarief, Ika Suryani. 2019. "Sejak 2017, SS Mencatat Ada 293 kasus lansia hilang karena demensia", https://www.suarasurabaya.net/kelanakota/2019/sejak2017-SS-Mencatat-Ada-293-Kasus-Lansia-HilangKarena-Demensia/, diakses pada 23 juni 2020 pukul 11.38.

[3] Rifai. Ahmad, "system informasi pemantauan posisi kendaraan dinas unsri menggunakan teknologi GPS", Jurnal SIstem Informasi (JSI), vol. 5, no. 2, pp. 503-610, 2013.

[4] Beny, Johan Budiman, dan Agus Nugroho, "Implementasi geofencing pada aplikasi layanan pemantauan anak berbasis lokasi", Seminar Nasional IPTEK Terapan (SENIT), pp 63-66, Tegal, 2017

[5] Rosso, Rendy Nusa, "Sistem Presensi Menggunakan Global Positioning System Berbasis Andoid", Universitas STIKUBANK Semarang, 2017.

[6] Putra, Dimas Maulana, M. Junus, dan Hadiwiyatno, "Rancang Bangun Pendeteksi Penghalang dan GPS Tracker Untuk Penyandang Tunanetra menggunakan Sarung Tangan Berbasis Mikrokontroler", Jurnal jaringan Telekomunikasi (JARTEL), vol. 9, no. 4, pp 442-451, 2019. 